\title{
Regulation of Human Umbilical Artery Contractility By Different Serotonin and Histamine Receptors
}

\author{
António José Santos-Silva, MD, Elisa Cairrão, MSc, Bruno Marques, MSc, and \\ Ignacio Verde, $\mathrm{PhD}$
}

\begin{abstract}
We studied the role of several serotonin (5-HT) and histamine receptors in the regulation of human umbilical artery (HUA) contractility. Among the 5-HT agonists used, only the 5-HT $\mathrm{T}_{2 A}$ and 5$H T_{1 B / D}$ agonists contracts $H U A$. The 5-HT-induced contractions were fully inhibited by ketanserin (5-HT $2 A$ antagonist). The 5-HT monophosphate (cAMP). Among the histamine receptor agonists, only betahistine ( $H_{1}$ agonist) induced significant contractile effect. Histamine-induced contraction was partially relaxed by pyrilamine ( $H_{1}$ antagonist). Betahistine-induced contraction was partially blocked by dimaprit $\left(\mathrm{H}_{2}\right.$ agonist) and by the $\mathrm{H}_{3}$ agonist when a low concentration of forskolin is present. Both, $\mathrm{H}_{2}$ and $\mathrm{H}_{3}$ agonists increased the cAMP intracellular levels in HUA smooth muscle. These findings show that in HUA, 5-HT $2 A^{-}$and $5-H T_{1 B / 1 D^{-a c t i v a t i o n}}$ lead to vasoconstriction and $5-H T_{7}$-activation induces vasorelaxation. Concerning histamine receptors, $\mathrm{H}_{1}$-activation induces contraction and $\mathrm{H}_{2}$-and $\mathrm{H}_{3}$-activation lead to vasorelaxation.
\end{abstract}

KEY wORDs: Umbilical cord, histamine, 5-HT, human, vascular smooth muscle, cyclic AMP.

\section{INTRODUCTION}

The mechanisms that regulate the contractile state of the smooth muscle cells in the human umbilical artery (HUA) are very important for optimum gas and nutrient exchange between the fetus and the placenta. Because the umbilical blood vessels are not innervated, the control of umbilical blood flow depends on vasoactive substances either released locally or existing in the circulation, ${ }^{1,2}$ such as serotonin (5-HT; 5-hydroxytryptamine) and histamine. As previously reported, $5-\mathrm{HT}^{1-3}$ and histamine ${ }^{4}$ induce significant contractions of HUA. The

From the CICS—Centro de Investigação em Ciências da Saúde, Universidade da Beira Interior, Av. Infante D. Henrique, Covilhã, Portugal (AJS-S, EC, BM, IV); and Centro Hospitalar da Cova da Beira. Quinta do Alvito, Covilhã, Portugal (EC).

Address correspondence to: Ignacio Verde, $\mathrm{PhD}$, Centro de Investigação em Ciências da Saúde, Universidade da Beira Interior, Av. Infante D. Henrique, 6200-506 Covilhã, Portugal. E-mail: iverde@fcsaude.ubi.pt.

Reproductive Sciences Vol. 16 No. 12 December 2009 1175-1185

DOI. 10.1177/1933719109343787

(C) 2009 The Author(s)
5-HT-induced contractions appear to be higher than those induced by histamine. ${ }^{5,6}$ The basal concentrations of these 2 substances in the umbilical artery blood of normal pregnant women during gestation are around $50 \mathrm{ng} / \mathrm{mL}$ for histamine and $5 \mathrm{ng} / \mathrm{mL}$ for $5-\mathrm{HT}^{7,8}$ However, several authors described that preeclampsia is associated with increase in histamine and 5-HT release and in the sensitivity of the HUA to these mediators, which can lead to increase of vascular resistance. ${ }^{9-12}$ Thus, 5-HT and histamine can regulate the HUA tone and are involved in some pathological processes that disturb umbilical circulation.

$5-\mathrm{HT}$ is a biogenic monoamine which mediates the smooth muscle contractility through the activation of different receptors $\left(5-\mathrm{HT}_{1}\right.$ to $\left.5-\mathrm{HT}_{7}\right) \cdot{ }^{13}$ Among them, $5-\mathrm{HT}_{1 \mathrm{~B}}, 5-\mathrm{HT}_{1 \mathrm{D}}, 5-\mathrm{HT}_{2 \mathrm{~A}}, 5-\mathrm{HT}_{2 \mathrm{~B}}, 5-\mathrm{HT}_{4}$, and $5-\mathrm{HT}_{7}$ receptors were shown to be expressed in blood vessels, even if messenger (mRNA) for $5-\mathrm{HT}_{2 \mathrm{~B}}$ and $5-\mathrm{HT}_{4}$ were only found in human endothelial cells. ${ }^{14}$ The $5-\mathrm{HT}_{1 \mathrm{~B}}$ and $5-\mathrm{HT}_{1 \mathrm{D}}$ receptors are coupled to $\mathrm{G}_{\mathrm{i}} / \mathrm{G}_{\mathrm{o}}$ protein, which inhibits adenylate cyclase. The $5-\mathrm{HT}_{2 \mathrm{~A}}$ receptor is positively coupled to $\mathrm{G}_{\mathrm{q}}$ protein. The $5-\mathrm{HT}_{7}$ receptor 
is coupled to $G_{s}$, which stimulates adenylate cyclase. ${ }^{15,16}$ Some studies on HUA revealed that the contractility induced by $5-\mathrm{HT}$ involves $5-\mathrm{HT}_{1 \mathrm{~B}}, 5-\mathrm{HT}_{1 \mathrm{D}}$, and $5-\mathrm{HT}_{2 \mathrm{~A}}$ receptors. ${ }^{3,12}$ Lovren et al showed that $5-\mathrm{HT}_{1 \mathrm{~B}}$ and $5-\mathrm{HT}_{2 \mathrm{~A}}$ receptors are expressed in HUA, but they did not find expression of $5-\mathrm{HT}_{1 \mathrm{D}}$ receptors in this artery. ${ }^{17} \mathrm{In}$ addition, recent data showed that the $5-\mathrm{HT}_{7}$ receptors mediate endothelium-independent relaxation of pig pulmonary artery. ${ }^{18}$ Despite these data, the role of these receptors in the regulation of HUA is still unclear.

Histamine is also a vasoactive substance that can activate different receptors $\left(\mathrm{H}_{1}\right.$ to $\left.\mathrm{H}_{4}\right) .{ }^{19}$ In general, $\mathrm{H}_{1}$ receptor couples to the $G_{\mathrm{q}}$ and causes mobilization of intracellular calcium. ${ }^{20}$ The $\mathrm{H}_{2}$ receptor causes cyclic adenosine monophosphate (cAMP) accumulation due to $\mathrm{G}_{\mathrm{s}}$ activation. ${ }^{20}$ The $\mathrm{H}_{3}$ receptor could be positively coupled to a $G_{i} / G_{o}$, although the intracellular signal transduction pathway initiated by the activation of this receptor is still under debate..$^{20-22}$ However, it was demonstrated that the $\mathrm{H}_{3}$ activation elicited a vasodilator response on some arteries, ${ }^{23,24}$ data that are contradictory with a decrease of cAMP intracellular levels. Concerning the $\mathrm{H}_{4}$ receptor, it could be functionally coupled to $\mathrm{G}_{\mathrm{i}} / \mathrm{G}_{\mathrm{o}}$ protein, causing either mobilization of intracellular calcium or inhibition of adenylate cyclase activity. ${ }^{25}$ Histamine can induce contractility or relaxation depending on the expression and/or participation of different types of histamine receptors in each specific vascular vessel. $^{13,26-28}$

In the current study, we studied the presence of different subtypes of 5-HT and histamine receptors and their functional role in the HUA tone regulation by using pharmacological, biochemical, and molecular approaches. Firstly, we examined the presence of mRNAs encoding different types of 5-HT and histamine receptors. Secondly, we examined the effects of different agonists and antagonists of different 5-HT and histamine receptors on the vasomotor tone. Also, to asses the adenylate cyclase regulation by some agonists of these receptors, the intracellular cAMP was measured in smooth muscle layers from HUA.

\section{MATERIAL AND METHODS}

\section{Tissue Preparation}

Umbilical cord pieces of 3 to $7 \mathrm{~cm}$, from the extremity closer to the newborn's $(20 \mathrm{~cm})$, were obtained from normal term pregnancies after vaginal delivery, with the consent of the donor mothers. All the procedures carried out using the umbilical cords were approved by the Ethics Committee of "Centro Hospitalar da Cova da Beira EPE." In total, 113 umbilical cord samples were collected in sterile physiological saline solution (PSS; composition, mmol/L: $\mathrm{NaCl} 110 ; \mathrm{CaCl}_{2} 0.15 ; \mathrm{KCl} 5 ; \mathrm{MgCl}_{2} 2$; HEPES 10; $\mathrm{NaHCO}_{3} 10 ; \mathrm{KH}_{2} \mathrm{PO}_{4}$ 0.5; $\mathrm{NaH}_{2} \mathrm{PO}_{4}$ 0.5; Glucose 10; EDTA 0.49). To avoid contamination and tissue degradation, penicillin $(5 \mathrm{U} / \mathrm{mL})$, streptomycin $(5 \mu \mathrm{g} / \mathrm{mL})$, amphotericin $\mathrm{B}(12.5 \mathrm{ng} / \mathrm{mL})$, and antiproteases (leupeptine $0.45 \mathrm{mg} / \mathrm{L}$, benzamidine $26 \mathrm{mg} / \mathrm{L}$, and trypsin inhibitor $10 \mathrm{mg} / \mathrm{L}$ ) were added to the PSS solution. Umbilical artery rings of 3 to $5 \mathrm{~mm}$ were isolated from the surrounding connective tissue. Vascular endothelium was mechanically removed by gentle rubbing with a cotton bud introduced through the arterial lumen. These denuded HUA rings were used to perform contractility experiments. Some HUA rings were chopped to rectangle pieces using scissors, and smooth muscle layers from the tunica media were extracted using surgical forceps and scalpel. The reverse transcriptase polymerase chain reaction (RT-PCR) and the cAMP radioimmunoassay experiments were performed using these tunica media layers.

\section{Analysis of the Expression of Histamine and 5-HT Receptors by RT-PCR}

Reverse transcriptase-polymerase chain reaction by using primers against the different 5-HT and histamine receptors subtypes was used to analyze their expression. The human housekeeping gene glyceraldehyde 3-phosphate dehydrogenase (GAPDH) was used to assess relative quantities of DNA from each sample. Total RNA was prepared from smooth muscle layers of human umbilical artery using the Tri reagent RNA purification system (Sigma, Saint Louis, Missouri). The complementary DNA (cDNA) was prepared from mRNA with random primers $(3 \mu \mathrm{g} / \mu \mathrm{L})$ using II RNAase H-reverse transcriptase and the conditions recommended by the manufacturer $(10 \mathrm{U} / \mu \mathrm{L})$. Five ng of cDNA were amplified in $25 \mu \mathrm{L}$ reaction mixture containing $200 \mu \mathrm{mol} / \mathrm{L}$ deoxyribonucleotide triphosphate (dNTPs), $0.625 \mathrm{U}$ of Taq-polymerase, and $25 \mathrm{pmol} / \mathrm{mL}$ of primers in buffer supplied by the manufacturer (Promega, Madison, Wisconsin). Oligonucleotide primers designed were as indicated in Table 1.

The PCR procedures were performed as follows: 35 cycles $\left(30\right.$ seconds at $94^{\circ} \mathrm{C}, 30$ seconds at $55^{\circ} \mathrm{C}-60^{\circ} \mathrm{C}$, and 
Table 1. Oligonucleotide Primers Designed to Analyze the Expression of Histamine $\left(\mathrm{H}_{1}\right.$ to $\left.\mathrm{H}_{4}\right)$ and 5-HT (5-HT $1 \mathrm{~B}, 5-\mathrm{HT}_{1 \mathrm{D}}$, 5- $\mathrm{HT}_{2 \mathrm{~A}}$, and 5- $\mathrm{HT}_{7}$ ) Receptors and Glyceraldehyde 3-Phosphate Dehydrogenase (GAPDH)

\begin{tabular}{|c|c|c|c|c|}
\hline Receptor & Genbank Number & Forward Primer & Reverse Primer & Fragment Size $(b p)$ \\
\hline $5-\mathrm{HT}_{1 \mathrm{D}}$ & NM000864 & $5^{\prime}$-tcctgaatccaccetcactc- $3^{\prime}$ & 5 '-gcagaaatcctcttgcgttc-3' & 196 \\
\hline $5-\mathrm{HT}_{7}$ & NM000872 & $5^{\prime}$-gaagagtgctgccaaacaca- $3^{\prime}$ & $5^{\prime}$-ggtggctgctttctgttctc- $3^{\prime}$ & 181 \\
\hline $\mathrm{H}_{1}$ & NM000861 & $5^{\prime}$-cacactgaacccctcatct- $3^{\prime}$ & $5^{\prime}$-ggccttcgtcctctatttcc- $3^{\prime}$ & 151 \\
\hline $\mathrm{H}_{2}$ & NM022304 & $5^{\prime}$-agcagcccagagtcagtcat- $3^{\prime}$ & $5^{\prime}-$ ccctggttgcttcttctctg- $3^{\prime}$ & 151 \\
\hline GAPDH & MN002046 & $5^{\prime}$-cgccagcccgagccacatc $-3^{\prime}$ & $5^{\prime}$-cgcccaatacgaccaaatccg- $3^{\prime}$ & 75 \\
\hline
\end{tabular}

30 seconds at $72^{\circ} \mathrm{C}$ ) and a final elongation (5 minutes at $\left.72^{\circ} \mathrm{C}\right)$. The PCR products were separated by electrophoresis on $1.5 \%$ agarose gel containing $0.01 \%$ of ethidium bromide and photographed under UV irradiation (320 nm).

\section{Artery Tension Recording}

The human umbilical artery rings were placed in organ bath (LE01.004, Letica) chambers containing Krebsbicarbonate solution (composition, mmol/L: $\mathrm{NaCl} 119$, $\mathrm{KCl}$ 5.0, $\mathrm{NaHCO}_{3} 25, \mathrm{KH}_{2} \mathrm{PO}_{4} 1.2, \mathrm{CaCl}_{2} 0.5, \mathrm{MgSO}_{4}$ 1.2 , EDTA 0.03 , glucose 11 ) at $37^{\circ} \mathrm{C}$ and continuously gassed with carbogen. The artery rings were suspended between 2 parallel stainless steel wires and tension measurement in grams (g) was performed using isometric transducers (TRI201, Panlab SA, Spain), amplifier (ML118/D Quad Bridge, ADInstruments), interface PowerLab/4SP (ML750, ADInstruments), and computerized system with Chart5 PowerLab software (ADInstruments). For analysis, the isometric tension measured was expressed in milligrams $(\mathrm{mg})$ of force elicited by the artery in presence of drugs. To analyze the relaxation data, we used the percentage of reduction on the maximal contraction induced by the contractile agents. During the resting periods, the organ bath solution was changed every 15 minutes. Initially, the rings were equilibrated for 60 minutes until a resting tension of 1 gram was achieved. This resting tension was previously used by other authors working with HUA ${ }^{29,30}$ and is supposed to be equivalent to $100 \mathrm{~mm} \mathrm{Hg}$ in the artery. After this, the rings were challenged with a supramaximal concentration of 5-HT $(1 \mu \mathrm{mol} / \mathrm{L})$ to test their viability. Rings that induced a maximal contraction lower than 1 gram when challenged with 5-HT were excluded from the study. To determine the involvement of distinct types of 5-HT and histamine receptors in the regulation of the vascular contractility supramaximal concentration of the following agonists and antagonists of these receptors were used ${ }^{12,31}$ : 5-hydroxytryptamine $(5-\mathrm{HT} ; 1 \mu \mathrm{mol} / \mathrm{L})$, unspecific agonist of 5-HT receptors; L-694,247 (L69; $1 \mu \mathrm{mol} / \mathrm{L}$ ), agonist of 5- $\mathrm{HT}_{1 \mathrm{~B}}$ and 5- $\mathrm{HT}_{1 \mathrm{D}}$ receptors; alpha-methyl-5-hydroxytryptamine (AMHT; $1 \mu \mathrm{mol} / \mathrm{L}$ ), agonist of $5-\mathrm{HT}_{2 \mathrm{~A}}$ receptors; ketanserin $(10 \mu \mathrm{mol} / \mathrm{L})$, antagonist of $5 \mathrm{HT}_{2 \mathrm{~A}}$ receptors; AS19 $(1 \mu \mathrm{mol} / \mathrm{L})$, agonist of $5-\mathrm{HT}_{7}$ receptors; histamine $(1 \mu \mathrm{mol} / \mathrm{L})$, unspecific agonist of histamine receptors; betahistine $(1 \mathrm{mmol} / \mathrm{L})$, agonist of $\mathrm{H}_{1}$ receptors; pyrilamine $(100 \mu \mathrm{mol} / \mathrm{L})$, antagonist of $\mathrm{H}_{1}$ receptors; dimaprit $(100 \mu \mathrm{mol} / \mathrm{L})$, agonist of $\mathrm{H}_{2}$ receptors; cimetidine $(10 \mu \mathrm{mol} / \mathrm{L})$, antagonist of $\mathrm{H}_{2}$ receptor; (R)-(-)-alpha-methylhistamine (RMH; $0.1 \mu \mathrm{mol} / \mathrm{L})$, agonist of $\mathrm{H}_{3}$ receptors; 4-methylhistamine (4-MH; $0.1 \mu \mathrm{mol} / \mathrm{L}$ ), agonist $\mathrm{H}_{4}$ receptors.

To further analyze the involvement of the cAMP pathway after the activation of some receptors, rolipram $(1 \mu \mathrm{mol} / \mathrm{L})$, a phosphodiesterase 4 (PDE4) specific inhibitor, or forskolin $(0.1$ or $10 \mu \mathrm{mol} / \mathrm{L})$, an adenylate cyclase activator, ${ }^{5}$ were used in some cases.

Control experiments with ethanol, the vehicle used to dissolve some drugs, were always performed.

\section{Cyclic AMP radioimmunoassay}

The HUA smooth muscle layers were weighted and incubated at $37^{\circ} \mathrm{C}$ for 30 minutes in Krebs solution with or without drugs. Afterward, the tissue samples were prepared according to the instructions provided by the manufacturer (cAMP EIA Kit, Cayman Chemical, Montluçon, France). Briefly, the layers were rapidly frozen using liquid nitrogen, homogenized in $500 \mu \mathrm{L}$ of $5 \%$ trichloroacetic acid (TCA). After homogenization, the extract was centrifuged, for 10 minutes at $1500 \mathrm{~g}$ and $4^{\circ} \mathrm{C}$. Trichloroacetic acid was 

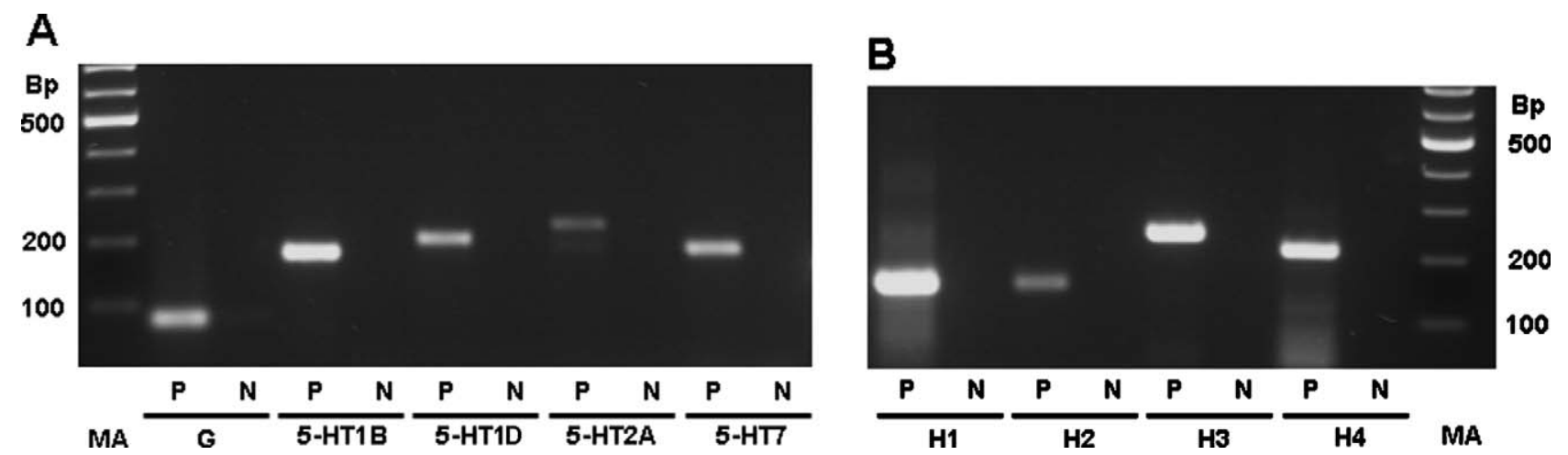

Figure 1. Expression analysis of different 5-HT and histamine receptors. Reverse transcriptase-polymerase chain reaction (RT-PCR) analysis was performed as described in the Material \& Methods section. Negative controls $(\mathrm{N})$ were performed in absence of messenger (mRNA) in contrast with that realized in presence $(\mathrm{P})$ of mRNA from human umbilical artery (HUA) smooth muscle layers. The PCR products were analyzed on a $1.5 \%$ agarose gel and pictures of the ethidium bromide stained gels are shown. A, Positive control using glyceraldehyde 3-phosphate dehydrogenase primers (G) and expression of 5-HT1B, 5-HT1D, negative 5-HT1D, 5-HT2A, and 5-HT7 receptors. B, Expression of $\mathrm{H} 1, \mathrm{H} 2, \mathrm{H} 3$, and $\mathrm{H} 4$ receptors. Positions of molecular weight markers (MA) are indicated in base pairs (bp).

extracted from the samples using water-saturated ether and finally the ether was eliminated by heating. The aqueous supernatant obtained was used for the cAMP assay according to the instructions provided by the manufacturer.

Control experiments with ethanol, the vehicle used to dissolve some drugs, were always performed.

\section{Drugs and Chemicals}

All drugs and chemicals were purchased from SigmaAldrich Quimica (Sintra, Portugal), except forskolin, rolipram, dimaprit, RMH, 4-MH, L69, AMHT, and AS19, which were purchased from Biogen Cientifica (Madrid, Spain). Forskolin, rolipram, betahistine, RMH, L69, and AS19, were initially dissolved in ethanol, and final solutions were obtained by dilution with Krebs solution. The final concentration of ethanol in the organ bath did not exceed $0.1 \%$. All the other drugs were initially dissolved in distilled water and final solutions were obtained by dilution with Krebs solution.

\section{Statistical Analysis}

Statistical treatment of data was performed using the SigmaStat Statistical Analysis System, version 1.00 (1992). Results are expressed as mean \pm SEM of $n$ experiments. Comparison among multiple groups was analyzed by using a one-way ANOVA followed by Tukey post hoc test to determine significant differences among the means. Multiple comparison between 2 groups was analyzed by using ANOVA followed by Dunnet's post hoc test. Probability levels lower than $5 \%$ were considered significant $(P<.05)$.

\section{RESULTS}

\section{Analysis of the Expression of Different 5-HT and Histamine Receptors}

Semi-quantitative RT-PCR analysis with specific primers was performed using HUA smooth muscle layers to check for the expression of $5-\mathrm{HT}_{1 \mathrm{~B}}, 5-\mathrm{HT}_{1 \mathrm{D}}, 5-\mathrm{HT}_{2 \mathrm{~A}}, 5-\mathrm{HT}_{7}$, $\mathrm{H}_{1}, \mathrm{H}_{2}, \mathrm{H}_{3}$, and $\mathrm{H}_{4}$ receptors. Positive controls were performed using glyceraldehyde 3-phosphate dehydrogenase primers (GAPDH) (Figure 1). Negative control experiments to confirm the absence of cDNA contamination from endothelial cells and fibroblast were performed with primers against Von Willibrand Factor and ICAM-1 and were always negative (data not shown). Also, negative controls to confirm the absence of DNA contamination during the experiences were performed in the absence of HUA smooth muscle cDNA (Figure 1).

Human umbilical artery smooth muscle expresses significant amounts of the following receptors: $5-\mathrm{HT}_{1 \mathrm{~B}}$, 5- $\mathrm{HT}_{1 \mathrm{D}}, 5-\mathrm{HT}_{2 \mathrm{~A}}, 5-\mathrm{HT}_{7}, \mathrm{H}_{1}, \mathrm{H}_{2}, \mathrm{H}_{3}$, and $\mathrm{H}_{4}$ (Figure 1). Concerning the level of expression of 5-HT receptors, the rank order is $5-\mathrm{HT}_{1 \mathrm{~B}}>5-\mathrm{HT}_{1 \mathrm{D}} \approx 5-\mathrm{HT}_{7}>5-$ $\mathrm{HT}_{2 \mathrm{~A}}$. For the histamine receptors, the rank order is $\mathrm{H}_{1}$ $>\mathrm{H}_{3} \approx \mathrm{H}_{4}>\mathrm{H}_{2}$. The expression of these receptors was detected in smooth muscle layers from 5 different HUA.

\section{Effects of Agonists and Antagonists of Different 5-HT Receptors on Contractility}

In the contractility experiments, the rings were placed in Krebs-bicarbonate solution with $0.5 \mathrm{mmol} / \mathrm{L} \mathrm{CaCl}_{2}$. In 


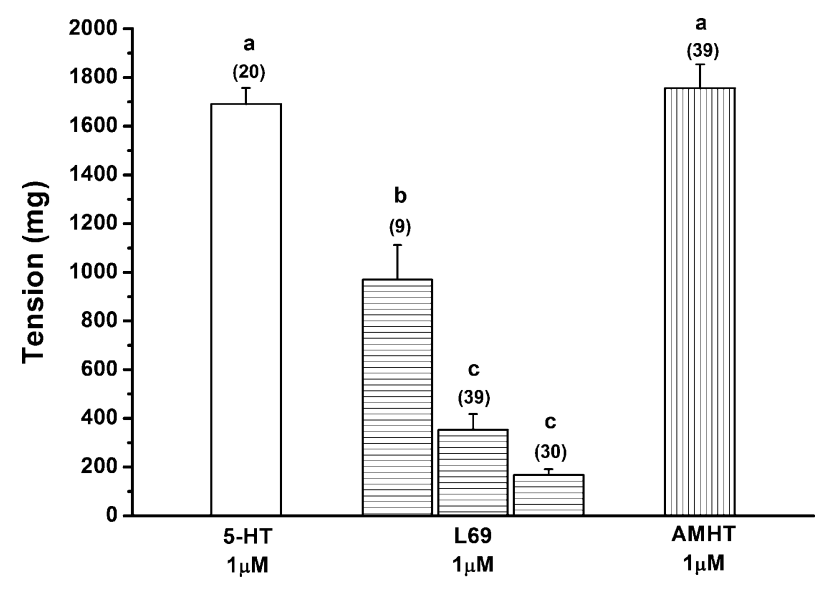

Figure 2. Contractile effect of 5-HT receptor agonists. Contractions $(\mathrm{mg})$ induced by $5-\mathrm{HT}(1 \mu \mathrm{mol} / \mathrm{L}), \mathrm{L} 69$ (5-HT1B/D agonist; $1 \mu \mathrm{mol} / \mathrm{L}$ ), and alpha-methyl-5-hydroxytryptamine (AMHT; 5HT2A agonist; $1 \mu \mathrm{mol} / \mathrm{L}$ ). The dual effect of L69 is indicated by 3 bars representing the high (left) and low (right) effects and the total effect (middle). The bars represent the mean and the lines the SEM of the number of experiments indicated near the bar. Different letters indicated significant differences and when bars do not share the same letter this means that there are significant differences $(\mathrm{P}<.05$, oneway ANOVA with Tukey post hoc test) between the effects.

fact, in the first experiments (data not shown), we used $1.5 \mathrm{mmol} / \mathrm{L}$ of $\mathrm{CaCl}_{2}$ and a consistent number of HUA rings did not contract in response to $5-\mathrm{HT}$ or KCl. Several authors, using concentrations of $\mathrm{CaCl}_{2}$ up of $1 \mathrm{mmol} / \mathrm{L}$, already experienced the same phenomenon. ${ }^{1,4,32}$ After testing several concentrations, we observed that, in contrast with upper concentrations, we always obtained consistent contractile effects using $0.5 \mathrm{mmol} / \mathrm{L}$ of $\mathrm{CaCl}_{2}$ in the Krebs solution. However, we also observed that the maximal contractile effect using this $\mathrm{CaCl}_{2}$ concentration was not decreased in contrast with upper concentrations (data not shown). In agreement with this, Okatani et al measured the contractile effect induced by $\mathrm{CaCl}_{2}$ in depolarizing medium and showed that $0.5 \mathrm{mmol} / \mathrm{L}$ of $\mathrm{CaCl}_{2}$ induces similar contraction than $1 \mathrm{mmol} / \mathrm{L}^{33}$

Human umbilical artery rings without endothelium were contracted by $5-\mathrm{HT}(1 \mu \mathrm{mol} / \mathrm{L})$ and stable contractions were attained after 5 to 10 minutes $(1690.2 \pm 67.0$ $\mathrm{mg})$. The involvement of different $5-\mathrm{HT}$ receptors on this effect was analyzed using specific agonists and antagonists of these receptors.

As shown in Figure 2, the $5-\mathrm{HT}_{2 \mathrm{~A}}$ agonist (AMHT; $1 \mu \mathrm{mol} / \mathrm{L}$ ) induced a contractile response that is similar to that induced by 5-HT $(P>.05)$. However, ketanserin $(10 \mu \mathrm{mol} / \mathrm{L})$, a $5-\mathrm{HT}_{2 \mathrm{~A}}$ antagonist, significantly relaxed $(88.2 \% \pm 6.6 \% ; \mathrm{n}=10)$ the rings contracted by $5-\mathrm{HT}$
$(P<.05)$. These data indicate that the major reason for the $5-\mathrm{HT}$ effect is the activation of $5-\mathrm{HT}_{2 \mathrm{~A}}$ receptors. Nevertheless, L69 $(1 \mu \mathrm{mol} / \mathrm{L})$, an agonist of the $5-\mathrm{HT}_{1 \mathrm{~B}}$ and $5-\mathrm{HT}_{1 \mathrm{D}}$ receptors, also induced contraction (352.8 $\pm 64.6 \mathrm{mg})$. However, we also observed that L69 did not induce the same contractile effect in all the HUA rings. As shown in the Figure 2, there are 3 bars to represent the effect of this agonist. The second bar represents the media of the contractile effect induced by L69 (39 arteries). From these 39 arteries, in 9 HUA (first bar; $969.7 \pm$ $143.1 \mathrm{mg}$ ) the contractile effect was huge when compared with the media (middle bar; $352.8 \pm 64.6 \mathrm{mg}$ ). The effect represented in the third bar corresponds to the other 30 arteries $(167.7 \pm 22.9 \mathrm{mg})$, in which the effect is not significantly different from the media (Figure 2). Thus, these data suggest that $5-\mathrm{HT}_{1 \mathrm{~B} / 1 \mathrm{D}}$ receptors can also participate in the 5-HT contractile effect, but there is variability in the response of this agonist in different HUA.

The involvement of $5-\mathrm{HT}_{7}$ receptor was also investigated. As this receptor was shown to be coupled to adenylate cyclase, we performed relaxing experiments on HUA contracted by a $5-\mathrm{HT}_{2 \mathrm{~A}}$ agonist (AMHT, $1 \mu \mathrm{mol} / \mathrm{L}$ ). The $5-\mathrm{HT}_{7}$ agonist (AS19, $1 \mu \mathrm{mol} / \mathrm{L}$ ) weakly relaxed the artery rings contracted by AMHT. This effect is similar to that obtained by adenylate cyclase stimulation with a supramaximal concentration of forskolin $(10 \mu \mathrm{mol} / \mathrm{L})$. As expected, the forskolin effect is increased when PDE4 is inhibited by rolipram $(1 \mu \mathrm{mol} / \mathrm{L})$. However, the relaxant effect induced by AS19 was not significantly increased in presence of rolipram (Figure 3). Figure 4A shows a record of an experiment in which AMTH-contracted arteries were relaxed by forskolin $(10 \mu \mathrm{mol} / \mathrm{L})$ and this effect is increased when rolipram $(1 \mu \mathrm{mol} / \mathrm{L})$ is further added.

Ethanol, the vehicle used to dissolve forskolin, rolipram, and AS19, did not have a significant relaxant effect at the concentrations used (data not shown).

\section{Effects of Agonists and Antagonists of Different Histamine Receptors on Contractility}

Human umbilical artery rings without endothelium were contracted by a supramaximal concentration of histamine $(1 \mu \mathrm{mol} / \mathrm{L})$ and stable contractions were attained after 5 to 10 minutes $(863.8 \pm 52.1 \mathrm{mg})$. The involvement of different histamine receptors on this effect was analyzed using specific agonists and antagonists of these receptors. 


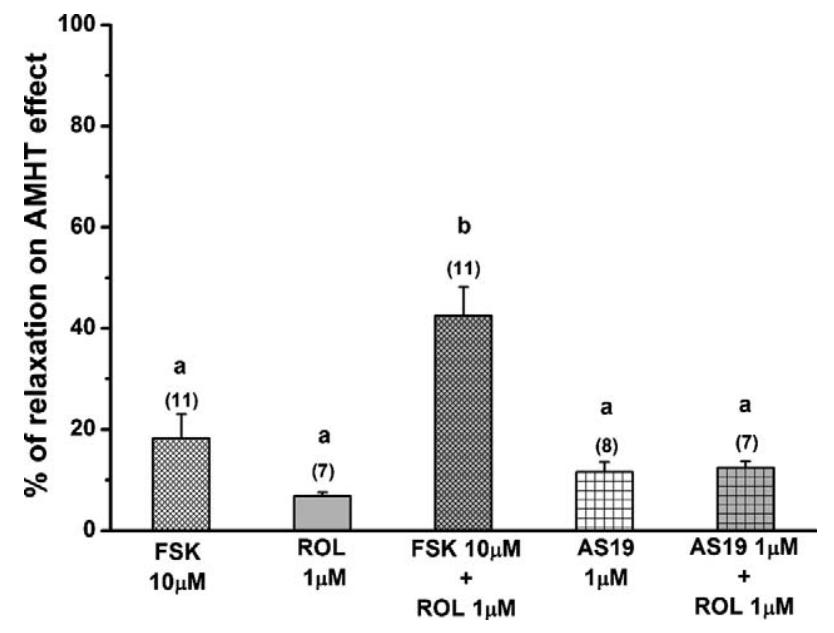

Figure 3. Relaxant effects of the 5-HT7 receptor activation and adenylate cyclase activation. The arteries were contracted by alphamethyl-5-hydroxytryptamine (AMHT; 5-HT2A agonist; $1 \mu \mathrm{mol} / \mathrm{L}$ ) and the percentage of relaxation of AS19 (5-HT7 agonist; $1 \mu \mathrm{mol} / \mathrm{L})$ and forskolin (FSK, adenylate cyclase activator; $10 \mu \mathrm{mol} / \mathrm{L}$ ) in absence and presence of rolipram (ROL, phosphodiesterase 4 inhibitor; $1 \mu \mathrm{mol} / \mathrm{L})$ is indicated. The bars represent the mean and the lines the SEM of the number of experiments indicated near the bar. Different letters indicated significant differences and when bars do not share the same letter this means that there are significant differences $(P<.05$, one-way ANOVA with Tukey post hoc test) between the effects.

Among the histamine receptor agonists used, excluding histamine, only a supramaximal concentration of the $\mathrm{H}_{1}$-receptor agonist betahistine $(1 \mathrm{mmol} / \mathrm{L})$ induced a significant contractile effect (Figure 5), which is higher than the contractile effect induced by histamine itself $(P<.05)$. However, the histamine-induced contraction was almost completely relaxed $(97.2 \% \pm 0.1 \%, \mathrm{n}=8)$ by pyrilamine $(100 \mu \mathrm{mol} / \mathrm{L}), \mathrm{a}_{1}$ antagonist. These data indicate that the major reason for the histamine effect is the activation of this receptor. However, the effect of betahistine is bigger than that of histamine, suggesting either that histamine is less selective for the $\mathrm{H}_{1}$ receptor or that histamine effect is the consequence of the activation of different receptors that signal to induce contraction and relaxation at the same time, resulting in a lower contractile effect.

The $\mathrm{H}_{2}$ receptor agonist dimaprit $(100 \mu \mathrm{mol} / \mathrm{L})$ did not induce contraction of HUA (Figure 5). To investigate a possible relaxant effect induced by the activation of $\mathrm{H}_{2}$ receptor, the action of dimaprit on rings contracted by an agonist $\mathrm{H}_{1}$ (betahistine; $1 \mathrm{mmol} / \mathrm{L}$ ) was analyzed. Dimaprit $(100 \mu \mathrm{mol} / \mathrm{L})$ partially relaxed $(25.3 \% \pm 2.0 \%, \mathrm{n}=$ 9) the contraction induced by betahistine. However, the effect of histamine was not significantly increased by the
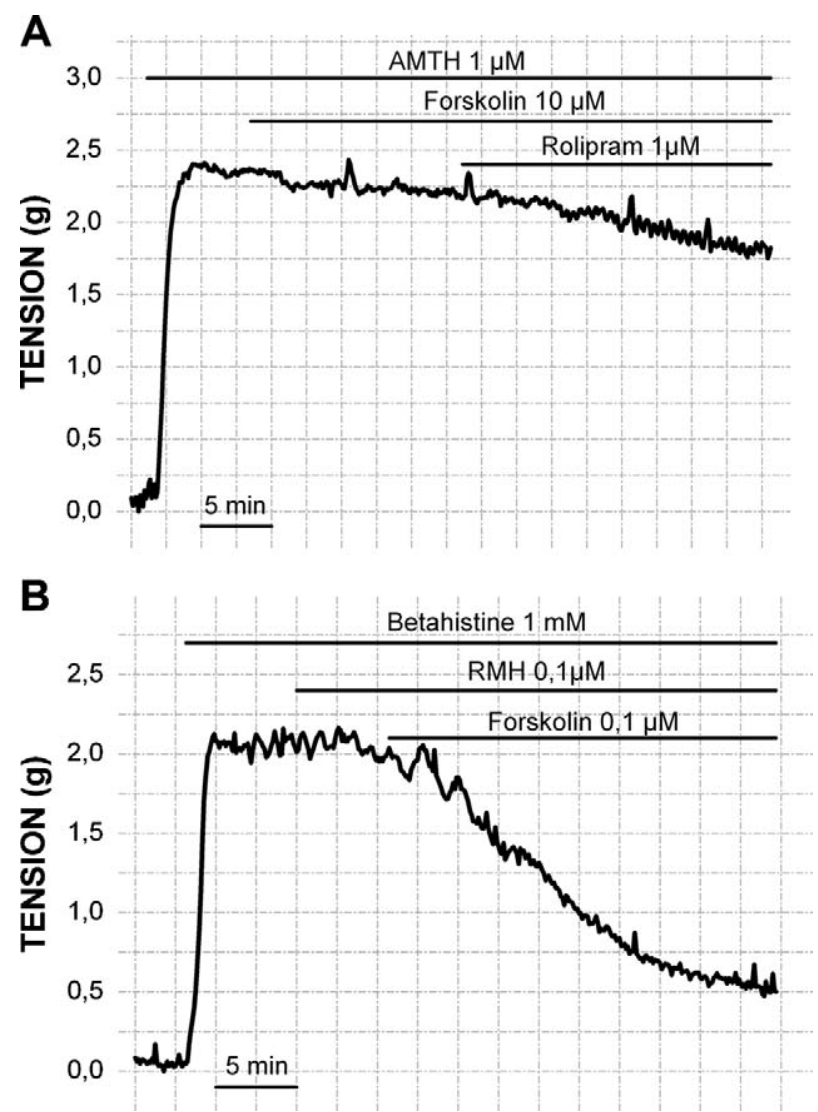

Figure 4. Original record of 2 tension experiments with human umbilical artery rings. A, The artery rings were contracted by alphamethyl-5-hydroxytryptamine (AMTH; $1 \mu \mathrm{mol} / \mathrm{L}$ ) and relaxed by forskolin $(10 \mu \mathrm{mol} / \mathrm{L})$ alone and in presence of rolipram $(1 \mu \mathrm{mol} / \mathrm{L})$; $\mathrm{B}$, The artery rings were contracted by betahistine $(1 \mathrm{mmol} / \mathrm{L})$ and relaxed by $(\mathrm{R})-(-)$-alpha-methylhistamine $(\mathrm{RMH} ; 0.1 \mu \mathrm{mol} / \mathrm{L})$ alone and in presence of forskolin $(0.1 \mu \mathrm{mol} / \mathrm{L})$.

presence of the $\mathrm{H}_{2}$-receptor antagonist cimetidine $(10 \mu \mathrm{mol} / \mathrm{L})$. However, the effect of these 2 drugs applied in combination was not significantly different than that induced by the $\mathrm{H}_{1}$ agonist BHI (Figure 5).

The involvement of $\mathrm{H}_{3}$ and $\mathrm{H}_{4}$ receptors was also investigated using $\mathrm{RMH}$ and 4-MH, agonists for $\mathrm{H}_{3}$ and $\mathrm{H}_{4}$ receptors, respectively. These agonists did not induce any contractile effect in HUA (Figure 5). When applied alone, RMH or 4-MH does not significantly relax contraction induced by the betahistine (Figure 6). As a supramaximal concentration of forskolin $(10 \mu \mathrm{mol} / \mathrm{L})$ elicited almost $100 \%$ of relaxation on betahistine-induced contractions (data not shown), we used a lower concentration $(0.1 \mu \mathrm{mol} / \mathrm{L})$, which relaxed around $40 \%$, to analyze if the agonists of $\mathrm{H}_{3}$ and $\mathrm{H}_{4}$ receptors increased this effect. The presence of RMH significantly increased the forskolin $(0.1 \mu \mathrm{mol} / \mathrm{L})$ effect on betahistine contracted arteries 


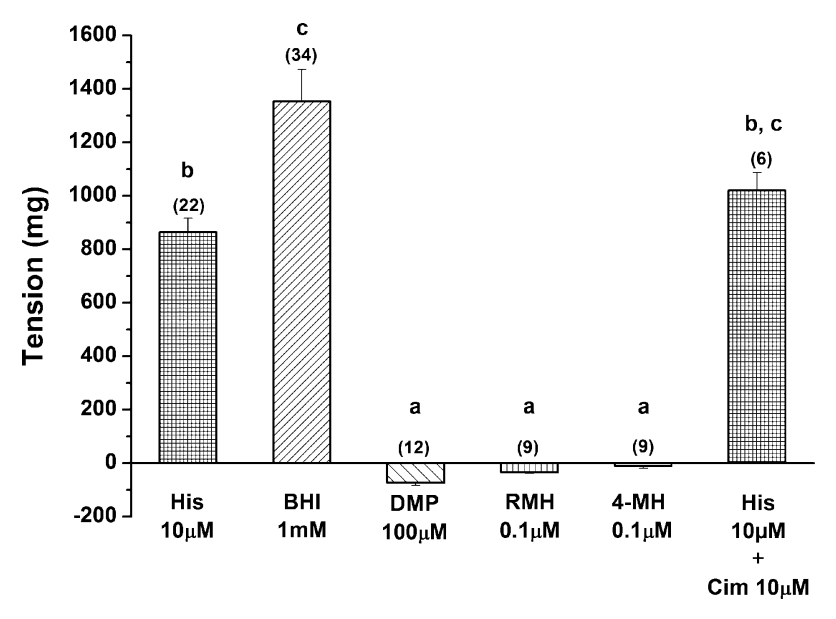

Figure 5. Contractile effect of different histamine receptor agonists. The contractile effect $(\mathrm{mg})$ induced by histamine (His; $10 \mu \mathrm{mol} / \mathrm{L})$, betahistine (BHI, H1 agonist; $1 \mathrm{mmol} / \mathrm{L}$ ), dimaprit (DMP, H2 agonist; $100 \mu \mathrm{mol} / \mathrm{L}), \mathrm{RMH}(\mathrm{H} 3$ agonist; $0.1 \mu \mathrm{mol} / \mathrm{L}), 4-\mathrm{MH}(\mathrm{H} 4$ agonist; $0.1 \mu \mathrm{mol} / \mathrm{L})$, and histamine in combination with cimetidine (Cim, H2 antagonist) is indicated. The bars represent the mean and the lines the SEM of the number of experiments indicated near the bar. Different letters indicated significant differences and when bars do not share the same letter this means that there are significant differences $(P<.05$, one-way ANOVA with Tukey post hoc test) between the effects.

(Figure 6), suggesting that the $\mathrm{H}_{3}$ receptors can induce relaxant effects through the cAMP pathway when the basal levels of this cyclic nucleotide are partially increased. However 4-MH did not increase the forskolin relaxant effect (Figure 6). Figure 4B shows a record of an experiment in which betahistine-contracted arteries were almost unaffected by RMH and this effect was increased when forskolin $(0.1 \mu \mathrm{mol} / \mathrm{L})$ was further added. However, the presence of 4-MH did not change the forskolin $(0.1 \mu \mathrm{mol} / \mathrm{L})$ relaxant effect (Figure 6).

Ethanol, the vehicle used to dissolve forskolin, rolipram, betahistine, RMH, and L69, did not have a significant relaxant effect at the concentrations used (data not shown).

\section{Effect of 5-HT and Histamine Agonists on Intracellular cAMP Concentration}

To analyze the involvement of the cAMP pathway in the effects induced by the activation of some 5-HT and histamine receptors in HUA smooth muscle, we examined the effects of some agonists of these receptors on the intracellular cAMP levels $\left([\mathrm{cAMP}]_{\mathrm{i}}\right)$.

As shown in Figure 7 , the basal level of $[\mathrm{cAMP}]_{\mathrm{i}}$ was $51.4 \pm 8.1 \mathrm{pmol} / \mathrm{mg}$ and forskolin $(10 \mu \mathrm{mol} / \mathrm{L})$, an

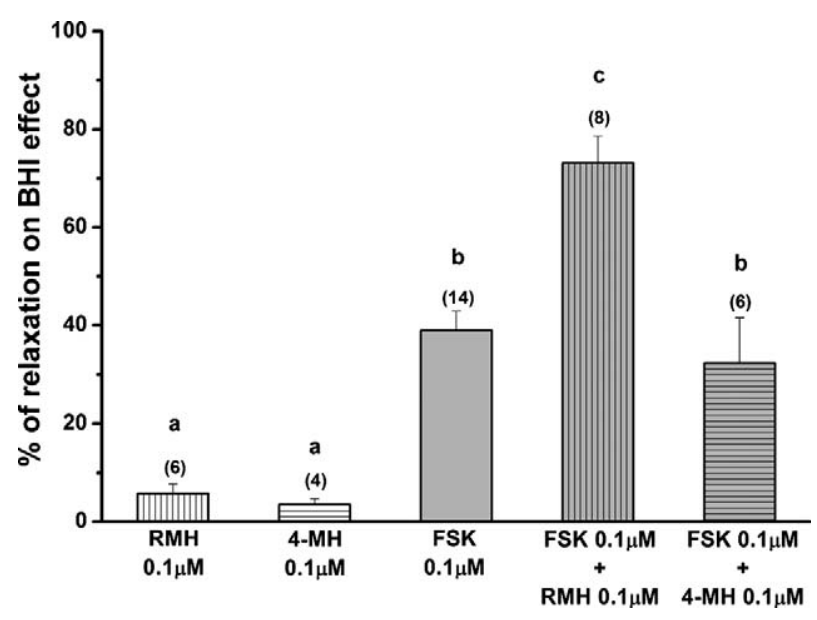

Figure 6. Relaxant effect of $\mathrm{H} 3$ and $\mathrm{H} 4$ receptor activation. Relaxant effects of RMH (H3 agonist; $0.1 \mu \mathrm{mol} / \mathrm{L})$ and 4-MH (H4 agonist; $0.1 \mu \mathrm{mol} / \mathrm{L}$ ) on betahistine (BHI, H1 agonist; $1 \mathrm{mmol} / \mathrm{L}$ ) contracted human umbilical artery (HUA) in presence and absence of adenylate cyclase activation by forskolin (FSK, $0.1 \mu \mathrm{mol} / \mathrm{L}$ ). The bars represent the mean and the lines the SEM of the number of experiments indicated near the bar. Different letters indicated significant differences and when bars do not share the same letter this means that there are significant differences $(P<.05$, one-way ANOVA with Tukey post hoc test) between the effects.

adenylate cyclase activator, significantly increased this level $(P<.05)$.

The $5-\mathrm{HT}_{1 \mathrm{~B} / \mathrm{D}}$ agonist, supposed to inhibit adenylate cyclase, did not significantly modify the basal $[\mathrm{cAMP}]_{\mathrm{i}}$. The agonist of $5-\mathrm{HT}_{7}$, supposed to activate the adenylate cyclase, did not significantly increase the $[\mathrm{cAMP}]_{\mathrm{i}}$, $(P=.09$; Figure 7$)$.

Concerning the histamine receptors, the agonists of $\mathrm{H}_{2}$ and $\mathrm{H}_{3}$ receptors increased the basal [cAMP] $]_{i}$ $(P<0.05)$. However, the agonist of $\mathrm{H}_{4}$ did not induce a significant increase in $[\mathrm{cAMP}]_{\mathrm{i}}$ (Figure 7 ).

Ethanol, the vehicle used to dissolve forskolin, AS19, $\mathrm{RMH}$, and L69, did not have a significant relaxant effect at the concentrations used (data not shown).

\section{DISCUSSION}

The tone of the umbilical artery is essential for fetal growth and development. Histamine and 5-HT are 2 key regulators of human umbilical artery (HUA) contractility and its effects can be mediated by the activation of different receptor types. Several authors described that increase of vascular resistance in some pathologies, as preeclampsia, is associated with increases in the release of histamine and 5-HT and in the sensitivity of the HUA to these 


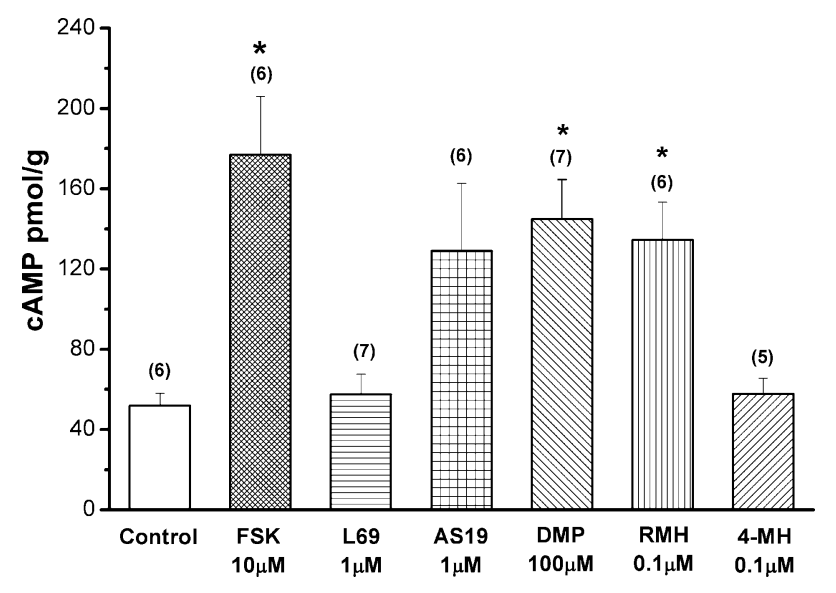

Figure 7. Effects of histamine and 5-HT receptor activation and forskolin on cyclic adenosine monophosphate (cAMP) intracellular levels. The cAMP intracellular level was analyzed in human umbilical artery (HUA) layers of HUA in absence (control) or presence of forskolin (FSK; $10 \mu \mathrm{mol} / \mathrm{L}$ ), L69 (agonist 5-HT1B/1D, $1 \mu \mathrm{mol} / \mathrm{L}$ ), AS19 (agonist 5-HT7, $1 \mu \mathrm{mol} / \mathrm{L}$ ), dimaprit (DMP, agonist $\mathrm{H} 2$; $100 \mu \mathrm{mol} / \mathrm{L}$ ), RMH (agonist H3, $0.1 \mu \mathrm{mol} / \mathrm{L}$ ), and 4-MH (agonist $\mathrm{H} 4,0.1 \mu \mathrm{mol} / \mathrm{L})$. The effects are expressed in pmol per $\mathrm{g}$ of cAMP. The bars indicate the mean and the lines the SEM of the number of preparations indicated near the bars. Statistical significant differences versus control effect was performed using one-way ANOVA with Dunnet's post hoc test $(\star P<.05)$.

mediators. ${ }^{9-12}$ Thus, further knowledge about the 5-HT and histamine receptors involved in the regulation of HUA contractility could open new perspectives useful for the treatment of some diseases.

In the current study, we analyzed the expression of different receptor subtypes of these signaling molecules and their role regulating denuded HUA contractility. According to the literature, the contractile effect of 5 -HT in denuded HUA can be due to the activation of 3 receptors subtypes ${ }^{12,17,34}: 5-\mathrm{HT}_{1 \mathrm{~B}}$ and $5-\mathrm{HT}_{1 \mathrm{D}}$ whose activation inhibits adenylate cyclase; and $5-\mathrm{HT}_{2 \mathrm{~A}}$ which activation increases inositol 1,4,5-triphosphate $\left(\mathrm{IP}_{3}\right)$ levels. As suggested by other authors, some of these receptors are important in the regulation of HUA tone. ${ }^{3,12,17}$ An increase in the sensibility to 5-HT in HUA arteries obtained from women with pregnancy-induced hypertension was observed, ${ }^{35}$ suggesting an involvement of these receptors in this pathology. Our data show that $5-\mathrm{HT}_{1 \mathrm{~B}}, 5-\mathrm{HT}_{1 \mathrm{D}}$, and $5-\mathrm{HT}_{2 \mathrm{~A}}$ receptors are expressed in HUA smooth muscle. Lovren et al already showed that $5-\mathrm{HT}_{1 \mathrm{~B}}$ and $5-\mathrm{HT}_{2 \mathrm{~A}}$, but in contrast with our results, these authors did not find expression of $5-\mathrm{HT}_{1 \mathrm{D}}$ in HUA. ${ }^{17}$ 5-HT and the selective $5-\mathrm{HT}_{2 \mathrm{~A}}$ agonist (AMHT) induced a similar degree of contractility and the $5-\mathrm{HT}_{2 \mathrm{~A}}$ antagonist (ketanserin) almost completely relaxed the HUA rings contracted by $5-\mathrm{HT}$. In agreement with other authors, ${ }^{3,12,17}$ our data suggest that the key receptor eliciting the HUA contractile response induced by serotonin is $5-\mathrm{HT}_{2 \mathrm{~A}}$. However, L69, a $5-\mathrm{HT}_{1 \mathrm{~B} / 1 \mathrm{D}}$ agonist, also induces contraction of HUA, even if these effects are dual because in most of the arteries it induced a small contractile effect $(167.7 \pm 22.9 \mathrm{mg})$ but in some cases a bigger contraction (around 1000 $\mathrm{mg}$ ) was obtained. Other authors showed that sumatrip$\tan$ and 5-nonyloxytryptamine $\left(5-\mathrm{HT}_{1 \mathrm{~B}}\right.$ and $5-\mathrm{HT}_{1 \mathrm{D}}$ agonists) do not always contract the HUA. They showed that only if the HUA is treated with a contractile subthreshold concentration of $\mathrm{KCl}$ or some agonists (prostaglandin F2a, U44069, histamine or 5-HT) then the sumatriptan and 5-nonyloxytryptamine contracted all HUA rings. ${ }^{17}$ However, in our case, the variability does not have relationship with the test response to 5-HT (performed to asses the viability of the rings). Other authors observed that $5-\mathrm{HT}_{1 \mathrm{~B} / 1 \mathrm{D}}$ receptor activation every time induces a consistent contraction of HUA. ${ }^{12}$ Verheggen et al, working with human occipital artery, demonstrated that the expression of these receptors is variable, because from 18 arteries analyzed, 3 arteries did not express the $5-\mathrm{HT}_{1 \mathrm{~B}}$ receptors and 4 did not express the $5-\mathrm{HT}_{1 \mathrm{D}}$ receptor. ${ }^{36}$ On the contrary, we detect expression of these receptors in 5 HUA smooth muscle layers analyzed. These receptors are negatively coupled with adenylate cyclase, which means that their activation can decrease the cAMP intracellular level. However, in agreement with other authors, ${ }^{15,16}$ our data did not show this, because the agonists of these receptors did not decrease the basal $[\mathrm{cAMP}]_{\mathrm{i}}$. Thus, even if the $5-\mathrm{HT}_{2 \mathrm{~A}}$ receptors are mainly responsible for 5-HT contractile effect of HUA, $5-\mathrm{HT}_{1 \mathrm{~B}}$ and/or 5-HT $1 \mathrm{D}$ are also involved, even if their contribution appears to be variable. Similar results were observed in human pulmonary ${ }^{37}$ and occipital ${ }^{36}$ arteries.

Contrary to the 5-HT receptors whose activation is coupled to induce vascular contractility, the $5-\mathrm{HT}_{7}$ receptors can mediate vascular relaxation because they are positively coupled to adenylate cyclase. These receptors were found to be expressed in different human arteries such as pulmonary and coronary arteries and aorta. ${ }^{14,38}$ Now, our data demonstrate that there is expression of $5-\mathrm{HT}_{7}$ receptors in HUA smooth muscle. In addition, the $5-\mathrm{HT}_{7}$ agonist (AS19) weakly relaxed $(11.6 \% \pm$ $2.0 \%$ ) the HUA rings contracted by AMHT and this effect was similar to that induced by the adenylate cyclase activator forskolin. Previously, Jahnichen et al observed that $5-\mathrm{HT}_{7}$ receptor activation induces endotheliumindependent relaxation of pig pulmonary artery. ${ }^{18} \mathrm{We}$ 
also performed some experiments using a PDE4 inhibitor to confirm the role of these receptors. As expected, the forskolin effect is increased when PDE4 is inhibited by rolipram, but the relaxant effect induced by AS19 was not significantly increased in the presence of rolipram. However, the activation of $5-\mathrm{HT}_{7}$ receptors did not increase induce a significant raise on cAMP. Nonetheless, for the first time, we show the expression of these receptors in HUA smooth muscle. The activation of these receptors induces a weak relaxing effect, suggesting that these receptors have a role in the regulation of the HUA contractility and could constitute a therapeutic target for the treatment of preeclampsia or hypertension in pregnancy to elude limitation in blood circulation between the mother and fetus.

Histamine has been shown to exert both contractile and dilating effects on different vascular smooth muscles. Usually, histamine induces contraction of large vessels and dilatation of small vessels. ${ }^{20}$ The involvement of different histamine receptors on this effect was analyzed using specific agonists and antagonists of several histamine receptor types. Our data show that only the $\mathrm{H}_{1}$-receptor agonist induces a significant contractile effect, which is higher than the contractile effect induced by histamine itself. These data suggest either that histamine is less selective for $\mathrm{H}_{1}$ receptor or that histamine effect is the consequence of the activation of different receptors inducing opposite effects. Histamine-induced contraction was almost completely relaxed by pyrilamine, a $\mathrm{H}_{1}$ antagonist, suggesting that the contractile effect is due to the activation of this receptor. The activation of $\mathrm{H}_{1}$ receptor increases $\mathrm{IP}_{3}$ and intracellular calcium levels. ${ }^{39}$ The importance of the $\mathrm{H}_{1}$ receptor to trigger vascular contractility in some arteries is also supported by other authors working with human radial and coronary arteries. ${ }^{40,41}$

In agreement with other studies, ${ }^{42}$ our data indicate that $\mathrm{H}_{2}$ receptors are also expressed in HUA smooth muscle. The activation of these receptors stimulates adenylate cyclase, increasing cAMP intracellular levels, ${ }^{20}$ a nucleotide which is related to artery vasorelaxation. ${ }^{5}$ The activation of these receptors induced relaxation $(25.3 \% \pm$ $2.0 \%$ ) of the HUA contracted by betahistine (agonist $\mathrm{H}_{1}$ ). Furthermore, the inhibition of these receptors induced a small increase of histamine-induced contractions. Besides, the effect of histamine and cimetidine applied in combination was not significantly different than that induced by the $\mathrm{H}_{1}$ agonist BHI. Daneshmand et al had also reported that stimulation of $\mathrm{H}_{2}$ receptor causes vasodilatation of human internal thoracic and radial arteries. $^{40}$ Moreover, Martinez et al showed that the vasodilatation of human dorsal penile artery induced by histamine seems to be mainly mediated by $\mathrm{H}_{2}$ receptors. ${ }^{43}$ Our results demonstrate that activation of $\mathrm{H}_{2}$ significantly increases $[\mathrm{cAMP}]_{\mathrm{i}}$ in HUA smooth muscle. The physiological implications of the $\mathrm{H}_{2}$-induced relaxation can be large, because Suzuki et al observed reduction in this relaxation in preeclampsia and suggested that this is due to the attenuation of the relaxing action of cAMP in these conditions. $^{44}$

Finally, our results demonstrate that $\mathrm{H}_{3}$ and $\mathrm{H}_{4}$ receptors are also expressed in HUA smooth muscle. The agonists for $\mathrm{H}_{3}$ and $\mathrm{H}_{4}$ receptors, $\mathrm{RMH}$ and 4-MH, respectively, did not induce any contractile effect in HUA. However, RMH and 4-MH did not significantly relax the contraction induced by betahistine. The signal transduction pathways involved in $\mathrm{H}_{3}$ receptor activation remain largely subject to speculation. Studies performed in nervous and heart cells suggested that this receptor is coupled to $G_{i}$ or $G_{0}{ }^{20}$. However, some authors have failed to observe an inhibition of adenylate cyclase activity in different tissues and cells. ${ }^{22,45}$ Other authors demonstrated that activation of this receptor relaxes rat mesenteric ${ }^{24}$ and horse penile dorsal arteries, ${ }^{23}$ an effect which is contradictory with the activation of $G_{i}$ protein which will lead to a decrease of cAMP levels. Studies performed in nonvascular cells suggested that alternative pathways can be triggered after the activation of the $\mathrm{H}_{3}$ receptor, such as inhibition of phospholipase $\mathrm{C}^{45}$ or activation of the MAPK-PLA 2 cascade. ${ }^{46}$ Our data show, for the first time, that the activation of the $\mathrm{H}_{3}$ receptor induces significant increase of [cAMP]i. The $\mathrm{H}_{3}$ agonist significantly increased the relaxing effect induced by low concentrations of forskolin $(0.1 \mu \mathrm{mol} / \mathrm{L})$, a cAMP elevating agent. Forskolin is a potent vasodilator of the histamine-contracted $\mathrm{HUA}^{5}$ and also relaxes betahistine-contracted arteries. These data suggest that the $\mathrm{H}_{3}$ receptors can induce relaxant effects through the cAMP pathway. Thus $\mathrm{H}_{3}$ activation does not activate $\mathrm{G}_{\mathrm{i}}$ protein, as indicated by other authors. Concerning the $\mathrm{H}_{4}$ receptors, it was reported that the activation of these receptors causes either mobilization of intracellular calcium or inhibition of the adenylate cyclase activity. ${ }^{25}$ Our data show that the activation of $\mathrm{H}_{4}$ receptor neither modulates the cAMP levels nor the HUA tone, even in presence of low concentrations of forskolin.

In conclusion, 5-HT and histamine can regulate HUA tone. 5-HT-induced contractions are mediated by the activation of $5-\mathrm{HT}_{2 \mathrm{~A}}$ receptors and partially by the activation of $5-\mathrm{HT}_{1 \mathrm{~B} / 1 \mathrm{D}}$ receptors. The activation of 5 $\mathrm{HT}_{7}$ induces relaxation of contracted HUA. Concerning 
the histamine receptors, $\mathrm{H}_{1}$ receptor activation induces contraction and $\mathrm{H}_{2}$ and $\mathrm{H}_{3}$ receptors activation mediates HUA relaxation through the increase of cAMP intracellular levels, although the pathway involved in the $\mathrm{H}_{3}$ activation needs to be further investigated. These data suggest that histamine and serotonin receptors are potential targets to develop a future therapeutic strategy for the treatment of some diseases as preeclampsia.

\section{ACKNOWLEDGMENTS}

We thank the donor mothers and the GynaecologyObstetrics Department staff of "Centro Hospitalar da Cova da Beira" (Covilhã, Portugal) for their disinterested collaboration and the "Fundação para a Ciência e a Tecnologia" (Portugal) for supporting the grant SFRH/ BDE/15532/2004.

\section{REFERENCES}

1. Tufan H, Ayan-Polat B, Tecder-Unal M, Polat G, Kayhan Z, Ogus E. Contractile responses of the human umbilical artery to $\mathrm{KCl}$ and serotonin in Ca-free medium and the effects of levcromakalim. Life Sci. 2003;72(12):1321-1329.

2. Leung SW, Quan A, Lao TT, Man RY. Efficacy of different vasodilators on human umbilical arterial smooth muscle under normal and reduced oxygen conditions. Early Hum Dev. 2006;82(7):457-462.

3. Karlsson C, Bodelsson G, Bodelsson M, Stjernquist M. Characterization of 5-hydroxytryptamine receptors mediating circular smooth muscle contraction in the human umbilical artery. Gynecol Obstet Invest. 1999;47(2):102-107.

4. Quan A, Leung SW, Lao TT, Man RY. 5-hydroxytryptamine and thromboxane A2 as physiologic mediators of human umbilical artery closure. J Soc Gynecol Investig. 2003;10(8):490-495.

5. Santos-Silva AJ, Cairrão E, Morgado M, Álvarez E, Verde I. PDE4 and PDE5 regulate cyclic nucleotides relaxing effects in human umbilical arteries. Eur J Pharmacol. 2008;582(1-3): 102-109.

6. Cairrao E, Alvarez E, Santos-Silva AJ, Verde I. Potassium channels are involved in testosterone-induced vasorelaxation of human umbilical artery. Naunyn Schmiedebergs Arch Pharmacol. 2008;376(5):375-383.

7. Mitchell RG, Porter JF. Histamine and granulocytes in the umbilical cord blood of infants at birth. $\mathrm{Br} J$ Pharmacol. 1970;40(2):310-316.

8. Taniguchi K. Vasospastic action of serotonin on the umbilical artery in normal and preeclamptic patients. J Obstet Gynaecol. 1995;21(1):37-42.
9. Bolte AC, van Geijn HP, Dekker GA. Pathophysiology of preeclampsia and the role of serotonin. Eur J Obstet Gynecol Reprod Biol. 2001;95(1):12-21.

10. Brew O, Sullivan $M H$. The links between maternal histamine levels and complications of human pregnancy. J Reprod Immunol. 2006;72(1-2):94-107.

11. Feinberg BB. Preeclampsia: the death of Goliath. Am J Reprod Immunol. 2006;55(2):84-98.

12. Gupta S, Hanff LM, Visser W, et al. Functional reactivity of 5-HT receptors in human umbilical cord and maternal subcutaneous fat arteries after normotensive or pre-eclamptic pregnancy. J Hypertens. 2006;24(7):1345-1353.

13. Nagai S, Tsurumaki T, Abe H, Higuchi H. Functional serotonin and histamine receptor subtypes in porcine ciliary artery in comparison with middle cerebral artery. Eur J Pharmacol. 2007;570(1-3):159-166.

14. Ullmer C, Schmuck K, Kalkman HO, Lubbert H. Expression of serotonin receptor mRNAs in blood vessels. FEBS Lett. 1995;370(3):215-221.

15. Pauwels PJ. Diverse signalling by 5-hydroxytryptamine (5-HT) receptors. Biochem Pharmacol. 2000;60(12):1743-1750.

16. Villalon CM, Centurion D. Cardiovascular responses produced by 5 -hydroxytriptamine:a pharmacological update on the receptors/mechanisms involved and therapeutic implications. Naunyn. Schmiedebergs Arch Pharmacol. 2007;376(1-2):45-63.

17. Lovren F, Li XF, Lytton J, Triggle C. Functional characterization and m-RNA expression of 5-HT receptors mediating contraction in human umbilical artery. $\mathrm{Br} J$ Pharmacol. 1999;127(5):1247-1255.

18. Jahnichen S, Glusa E, Pertz HH. Evidence for 5-HT2B and 5HT7 receptor-mediated relaxation in pulmonary arteries of weaned pigs. Naunyn Schmiedebergs Arch Pharmacol. 2005; 371(1):89-98.

19. Leurs R, Smit MJ, Timmerman H. Molecular pharmacological aspects of histamine receptors. Pharmacol Ther. 1995;66(3): 413-463.

20. Hill SJ, Ganellin CR, Timmerman H, et al. International Union of Pharmacology. XIII. Classification of histamine receptors. Pharmacol Rev. 1997;49(3):253-278.

21. Lovenberg TW, Roland BL, Wilson SJ, et al. Cloning and functional expression of the human histamine $\mathrm{H} 3$ receptor. Mol Pharmacol. 1999;55(6):1101-1107.

22. Levi R, Smith NC. Histamine H(3)-receptors: a new frontier in myocardial ischemia. J Pharmacol. Exp Ther. 2000;292(3): 825-830.

23. Martinez AC, Rivera L, Raposo R, Garcia-Sacristan A, Benedito S. Evidence of histamine receptor function in isolated horse penile dorsal arteries. Life Sci. 2000;67(11): 1355-1368.

24. Obuchowicz R, Pawlik MW, Brzozowski T, Konturek SJ, Pawlik WW. Involvement of central and peripheral histamine $\mathrm{H}(3)$ receptors in the control of the vascular tone and oxygen uptake in the mesenteric circulation of the rat. J Physiol Pharmacol. 2004;55(1 pt 2):255-267. 
25. de Esch IJ, Thurmond RL, Jongejan A, Leurs R. The histamine $\mathrm{H} 4$ receptor as a new therapeutic target for inflammation. Trends Pharmacol Sci. 2005;26(9):462-469.

26. Zhang DX, Gauthier KM, Campbell WB. Mechanisms of histamine-induced relaxation in bovine small adrenal cortical arteries. Am J Physiol. 2005;289(6):E1058-1063.

27. Schultheiss G, Hennig B, Schunack W, Prinz G, Diener M. Histamine-induced ion secretion across rat distal colon: involvement of histamine $\mathrm{H} 1$ and $\mathrm{H} 2$ receptors. Eur J Pharmacol. 2006;546(1-3):161-170.

28. Jin H, Koyama T, Hatanaka Y, Akiyama S, Takayama F, Kawasaki $H$. Histamine-induced vasodilation and vasoconstriction in the mesenteric resistance artery of the rat. Eur J Pharmacol. 2006;529(1-3):136-144.

29. Fiscus RR, Dyer DC. Effects of indomethacin on contractility of isolated human umbilical artery. Pharmacolog $\gamma$. 1982;24(6): 328-336.

30. MacLennan SJ, Whittle MJ, McGrath JC. 5-HT1-like receptors requiring functional cyclo-oxygenase and 5-HT2 receptors independent of cyclo-oxygenase mediate contraction of the human umbilical artery. Br J Pharmacol. 1989;97(3): 921-933.

31. Martinez AC, Novella S, Raposo R, et al. Histamine receptors in isolated bovine oviductal arteries. Eur J Pharmacol. 1997;326(2-3):163-173.

32. Wylam ME, Samsel RW, Schumacker PT, Umans JG. Extracellular calcium and intrinsic tone in the human umbilical artery. J Pharmacol Exp Ther. 1993;266(3):1475-1481.

33. Okatani Y, Wakatsuki A, Reiter RJ. Protective effect of melatonin against homocysteine-induced vasoconstriction of human umbilical artery. Biochem Biophys Res Commun. 2000; 277(2):470-475.

34. Rogines-Velo MP, Pelorosso FG, Zold CL, et al. Characterization of 5-HT receptor subtypes mediating contraction in human umbilical vein. 1. Evidence of involvement of 5HT2A receptors using functional and radioligand binding assays. Naunyn Schmiedebergs Arch Pharmacol. 2002;366(6): 587-595.

35. Johnstone FD, Ugaily-Thulesius L, Thulesius O, Nasrat AN. Umbilical artery reactivity and ultrastructural changes in pregnancy-induced hypertension and other complicated pregnancies. Clin Physiol. 1987;7(6):493-502.
36. Verheggen R, Meier A, Werner I, et al. Functional 5-HT receptors in human occipital artery. Naunyn Schmiedebergs Arch Pharmacol. 2004;369(4):391-401.

37. Cortijo J, Marti-Cabrera M, Bernabeu E, et al. Characterization of 5-HT receptors on human pulmonary artery and vein: functional and binding studies. Br J Pharmacol. 1997;122(7): 1455-1463.

38. Nilsson T, Longmore J, Shaw D, et al. Characterisation of 5-HT receptors in human coronary arteries by molecular and pharmacological techniques. Eur J Pharmacol. 1999;372(1):49-56.

39. Hawley J, Rubin PC, Hill SJ. Distribution of receptors mediating phosphoinositide hydrolysis in cultured human umbilical artery smooth muscle and endothelial cells. Biochem Pharmacol. 1995;49(7):1005-1011.

40. Daneshmand MA, Keller RS, Canver MC, Canver AC, Canver CC. Histamine $\mathrm{H} 1$ and $\mathrm{H} 2$ receptor-mediated vasoreactivity of human internal thoracic and radial arteries. Surgery. 2004;136(2):458-463.

41. Keitoku M, Maruyama Y, Takishima T. The receptor mechanisms for histamine actions in proximal portion differ from those in distal portion in human coronary artery. Tohoku J Exp Med. 1988;154(4):415-416.

42. Schneider A, Riess P, Elbers A, Neugebauer E, Schaefer U. Polyclonal anti-histamine $\mathrm{H} 2$ receptor antibodies detect differential expression of $\mathrm{H} 2$ receptor protein in primary vascular cell types. Inflamm Res. 2004;53(6):223-229.

43. Martinez AC, Prieto D, Raposo R, et al. Endothelium-independent relaxation induced by histamine in human dorsal penile artery. Clin Exp Pharmacol Physiol. 2000;27(7):500-507.

44. Suzuki Y, Saitoh M, Suzumori K, Kajikuri J, Itoh T. Characterization of changes in mechanical responses to histamine in omental resistance arteries in pre-eclampsia. $\mathrm{Br} J$ Pharmacol. 2000;131(1):37-42.

45. Cherifi Y, Pigeon C, Le Romancer M, Bado A, ReylDesmars F, Lewin MJ. Purification of a histamine $\mathrm{H} 3$ receptor negatively coupled to phosphoinositide turnover in the human gastric cell line HGT1. J Biol Chem. 1992;267(35): 25315-25320.

46. Levi R, Seyedi N, Schaefer U, et al. Histamine H3-receptor signaling in cardiac sympathetic nerves: Identification of a novel MAPK-PLA2-COX-PGE2-EP3R pathway. Biochem Pharmacol. 2007;73(8):1146-1156.

For reprints and permissions queries, please visit SAGE's Web site at http://www.sagepub.com/journalsPermissions.nav 